\title{
BETWEEN HALAL AND HARAM: THE CHALLENGES AND ADAPTATION OF HALAL DIETARY CONSUMPTION INDONESIAN MUSLIM IMMIGRANTS IN JAPAN
}

\author{
Arina Lintang Iklima ${ }^{1 *}$, Yayuk Yuliati, ${ }^{2}$ Anif Fatma Chawa ${ }^{3}$ \\ ${ }^{1}$ Brawijaya University, Malang, East Java, Indonesia, email: arinalintangiklima@gmail.com \\ ${ }^{3}$ Brawijaya University, Malang, East Java, Indonesia, email:yayuk.yyl@gmail.com \\ ${ }^{2}$ Brawijaya University, Malang, East Java, Indonesia, email: anif chawa@,ub.ac.id \\ ${ }^{*}$ Corresponding Author
}

\author{
(c) (i) (2) \\ (C)2021 by the authors. Submitted for possible open access publication under the terms and conditions of the Creative Commons \\ Attribution-ShareAlike 4.0 International License-(CC-BY-SA) (https://creativecommons.org/licenses/by-sa/4.0/)

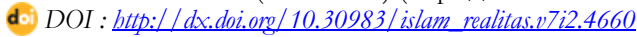 \\ Submission: 17 August $2021 \quad$ Revised: 14 November $2021 \quad$ Published: 31 December 2021
}

\begin{abstract}
This study examines the challenges and adaptation strategies of Halal food consumption by Indonesian Muslim immigrants in Japan. Since April 2019, Japan's government decided to accept foreign workers under Specified Skills Visa Program to address the labor shortages in the country. This new policy will encourage more Muslim immigrants from Indonesia to search for higher income in Japan. The growing population of Muslim immigrants in Japan and inbound tourists from Islamic countries has triggered the development of Halal food products in Japan. The research uses a qualitative approach supplemented with semi-structured interviews of Indonesian Muslim Immigrants from various locations in Japan. This study has found that the Indonesian Muslim immigrants face three challenges to maintain their Halal dietary consumption. The different culture of social life has put social pressure on Muslim immigrants to follow the Japanese drinking and hangout habits. The difficulties of accessibility and a lack of variety of Halal food products make it a less appealing choice for busy-scheduled people. There is no legal body that has the authority to give Halal certification. Theory of deviance typology is used to analyze the adaptation strategy formed as the result of these challenges. There are four types of adaptation strategy formed by Indonesia Muslim immigrants: Conformity, Innovation, Ritualism, and Retreatism.
\end{abstract}

Keywords: Halal dietary, Challenges and adaptation, Muslim immigrants, Japan.

\begin{abstract}
Abstrak
Penelitian ini mengkaji tentang tantangan dan strategi adaptasi konsumsi makanan halal oleh imigran Muslim Indonesia di Jepang. Sejak. April 2019, pemerintah Jepang memutuskan untuk menerima pekerja asing di bawah Program Visa Keterampilan Khusus untuk mengatasi kekurangan tenaga kerja di Jepang. Kebijakan baru ini akan mendorong lebih banyak imigran Muslim dari Indonesia untuk mencari penghasilan yang lebih tinggi di Jepang. Meningkatnya populasi imigran Muslim di Jepang dan masuknya turis dari negara-negara Islam telab memicu berkembangnya produk makanan Halal di Jepang. Penelitian ini menggunakan pendekatan kualitatif yang dilengkapi dengan wawancara semi terstruktur terhadap Imigran Muslim Indonesia dari berbagai lokasi di Jepang. Studi ini menemukan bahwa para imigran Muslim Indonesia memiliki tiga tantangan untuk mempertahankan konsumsi makanan halal mereka. Budaya kebidupan sosial yang berbeda telah memberikan tekanan sosial bagi imigran Muslim untuk mengikuti kebiasaan minum alkohol dan cara pergaulan orang Jepang. Kesulitan aksesibilitas dan kurangnya variasi produk makanan balal menjadikannya pilihan yang kurang menarik bagi orang-orang dengan jadwal sibuk. Tidak ada satu pun badan bukum yang berwenang memberikan sertifikasi halal. Teori tipologi penyimpangan digunakan untuk menganalisis strategi adaptasi yang terbentuk akibat tantangan tersebut. Ada empat jenis strategi adaptasi yang dibentuke oleh Imigran Muslim Indonesia: Conformity, Innovation, Ritualism, and Retreatism.
\end{abstract}

Kata kunci: Makanan halal, Tantangan dan adaptasi, Imigran Muslim, Jepang.

\section{Background}

The Halal industry has seen major growth in the recent decades. Both Muslim and non-Muslim countries are competing in the Halal Industry to gain the most profit. The word "halal" is derived from the verb "halla" which means lawful, legal, licit, legitimate or permitted (for Muslims), and it 
has important influence for Muslim consumer to purchase and consume permissible products in according to the Shariah Islamic Law. ${ }^{1}$ Meanwhile, the term "haram" (Arabic: "مارح"), which means in Arabic forbidden or unlawful is the antonym of the term "halal". 2 The Islamic legal obligation of a Muslim to consume Halal and tayyib ("good") has been regarded as a big opportunity to develop new market: the Halal market. Additionally, the increasing number of the Muslim population with their expenditure on food, beverage, finance, tourism, etc., has become the driving force for its development. Based on the report from State of the Global Islamic Economy Report 2020/2021, the global Islamic market is now valued at $\$ 2.88$ trillion with food spending of Muslims seeing an increase of $3.1 \%$ from $\$ 1.13$ trillion in 2018 to $\$ 1.17$ trillion in 2019. Moreover, the Covid-19 crisis is not likely to lead to a significant drop, only around $0.2 \%$ forecasted in Muslim spending for $2020 .^{3}$

The growth of Halal food industry has been realized not only by Muslim countries, but also by non-Muslim countries such as Japan. This country is known for its beautiful nature and rich culture which has made it one of the most famous international tourist destinations. There are many travelers from Muslim countries who choose to visit Japan due to its typical tolerant culture towards religions. Japan has demonstrated their support on providing more Halal-friendly environments for Muslims by establishing Halal restaurants and Muslim prayer rooms at some of their airports. For instance, in preparation for the
2020 Tokyo Olympics which was rescheduled to 2021 due to Covid-19 pandemic, Japan has entered into an agreement with Malaysia's Halal Development Corporation (HDC) to provide Halal necessities for the event. ${ }^{4}$

Even as a minority, the Muslim population in Japan continue to increase. According to Hirofumi Tanada, a well-known Japanese academic from Waseda University studying the Japanese Muslim communities and Islam in Japan, the number of Muslims living in Japan has doubled in a decade from 110,000 in 2010 to 230,000 by the end of $2019 .{ }^{5}$ This is makes up less than $1 \%$ of total Japan's population. The majority of Japanese Muslim population are from Asia. Asian Muslims has grown in recent years due to an increasing share of Indonesian and Malaysian Muslims participating the Japanese Technical Intern Training Program. ${ }^{6}$

However, the negative labeling of Muslims as potentially dangerous and terror has led to social marginalization, linguistic and cultural barriers, and other problems. ${ }^{7}$ Also, the strict and clear instruction in the religion for the consumption of Halal products and the obligations upon Muslims commonly referred to as the Five Pillars, which consist of the testimony of faith (shahadab), daily prayers (salah), alms-tax (zakat), fasting (sawm), and the pilgrimage to Mecca (baj), have imposed major challenges in their adaptation to a nonMuslim environment.

There are a lot of challenges for Muslim minorities in Japan especially for those who are devoted. The requirement to only consume Halal
1 Carrie Amani Annabi and Olufunbi Olajumoke Ibidapo-Obe, 'Halal Certification Organizations in The United Kingdom: An Exploration of Halal Cosmetic Certification', Journal of Islamic Marketing, 8.1 (2017), 107-26 <https://doi.org/10.1108/JIMA-06-2015-0045>.

2 Abdelhadi Halawa, 'Acculturation of Halal Food to the American Food Culture through Immigration and Globalization: A Literature Review', Journal of Ethnic and Cultural Studies, 5.2 (2018), 53-63 <https://doi.org/10.29333/ejecs/89>.

3 DinarStandard, 'State of the Global Islamic Economy Report 2020/2021', Salaam Gateway, 2019, 3-4 $<$ https://cdn.salaamgateway.com/special-coverage/sgie1920/ full-report.pdf $>$.
${ }^{4}$ Dinar Standard.

${ }^{5}$ Hiji Hajis, 'The Number of Muslims in Japan Is Growing Fast', The Economist, 2021 <https://www.economist.com/asia/2021/01/07/thenumber-of-muslims-in-japan-is-growing-fast $>$.

${ }^{6}$ SESRIC, 'Muslim Communities and Minorities in Non-OIC Member States: Japan', Global Muslim Diaspora Project. Human and Social Development Studies., 2019, 8.

7 Ali Amin, 'From Mushalla to Mosque: The Formation of South and Southeast Asian Muslim Communities in Japan', Al-Albab, 8.1 (2019), 3 <https://doi.org/10.24260/alalbab.v8i1.1050>. 
food has become a significant concern for the Muslim community. The availability and accessibility of Halal food in Japan has increased rapidly in the recent years with the boom of Halal certification in Japan's food Industry. ${ }^{8}$ It is important for Muslims that Halal products are certified as Halal to ensure that the products have met the Islamic guidelines thoroughly. ${ }^{9}$ However, in the reality there are some issues that needs to be confronted to get the Halal food products. The variety of food products are so limited, so people usually need to find alternatives by visiting special Halal food shops located faraway. There is no global standard for Halal certification used in Japan which has led to trust issues for Muslims. ${ }^{10}$ Additionally, the uncommon culture to check Halal and non-Halal products for people from Muslim countries also need to be addressed.

There have been many previous studies about consumer behavior in consuming Halal products. Some of those scholars namely Zulkifli et al. ${ }^{11}$, Moklis ${ }^{12}, \mathrm{Fasa}^{13}$, Reman et $\mathrm{al}^{14}$ and Ainur and $\operatorname{Titan}^{15}$ have found that the level of one's religious observance greatly influences their decision to consume Halal food. Additionally, studies on the consumption of Halal food by Indonesian Muslim immigrants have been conducted in Belgium and

${ }^{8}$ Hiroko Kurosaki Yamaguchi, 'The Potential and Challenge of Halal Foods in Japan', Journal of Asian Rural Studies, 3.1 (2019),

<https://doi.org/10.20956/jars.v3i1.1712>.

9 Annabi and Ibidapo-Obe.

${ }^{10}$ Yamaguchi.

11 Zulkufly Ramly, Lau Teck Chai, and Choe Kum Lung, 'Religiosity as a Predictor of Consumer Ethical Behaviour: Some Evidence from Young Consumers from Malaysia', Journal of Business Systems, Governance and Ethics, 3.4 (2008) < https://doi.org/10.15209/jbsge.v3i4.147>.

12 Safiek Mokhlis, 'Relevancy and Measurement of Religiosity in Consumer Behavior Research', International Business Research, 2.3

<https://doi.org/10.5539/ibr.v2n3p75>.

13 Muhammad Iqbal Fasa, 'Critical Review: Is Religiousity an Important Determinant on Muslim Consumer Behavior In Malaysia?', IJRDO-Journal of Applied Management Science, 2.8 (2016), 13-21.

14 Ateeq-ur- Rehman and Muhammad Shahbaz Shabbir, 'The Relationship Between Religiosity and New Product Adoption', Journal of Islamic Marketing, 1.1 (2010), 63-69 <https://doi.org/10.1108/17590831011026231>. the Netherlands. The results in the Netherlands indicate that access to Halal food is progressively supported by the Halal food industry in the country, which has shown a significant increase in the last 10 years. ${ }^{16}$ Meanwhile in Belgium, the study found that the desire to consume Halal food is very much determined by the level of obedience to the religion, the influence of social pressure, and the ability to obtain Halal food ${ }^{17}$. There has been a lot of research and discussion about the Muslim growth and the opportunity of Halal food Industry in Japan. A previous research about the role of the Muslim community to change the negative image about Islam in Japan has also discussed the limited number of Halal shops and restaurants in Japan. ${ }^{18}$ However, other studies shows that the number of Japanese companies and municipalities that are interested in Halal industry and obtaining the certification has been increasing throughout the years. ${ }^{19}$

Despite the studies mentioned above, the challenges being faced by Muslims immigrants in Japan, and the various ways they adapt to these challenges have not been discussed. The majority of the previous studies about Halal consumption behavior used quantitative research method. In particular, the discussion from the perspective of

15 Ainur Rofiq \& Titan Achsan, 'Examining the Impacts of Religiosity, Attitude, and Subjective Norm Toward Intention to Purchase Halal Food: A Study on Indonesian Muslim Consumers', Jurnal Ilmiah Mahasiswa Fakultas Ekonomi dan Bisnis, $05 \quad$ (2017) $<$ https://jimfeb.ub.ac.id/index.php/jimfeb/article/view/3 $850>$.

16 Mariko Arata, 'Getting Halal Food in the Netherlands: From Indonesian Consumers' Perspective', in Proceedings of the International Workshop on Halal Food Consumption in East and West, 2018, pp. 35-48 $<$ https://www.academia.edu/ $>$.

${ }^{17}$ Ayang Utriya Yakin and Ima Sri Rahmani, 'Halal Food Consumption among the Indonesian Muslim Minority in Belgium', in Proceedings of the International Workshop on 'Halal Food Consumption in East and West' (Tokyo: Institute for Asian Muslim Studies, Waseda University, 2018), pp. 123-50.

${ }^{18}$ Irma Rachmi Yulita and Susy Ong, 'The Changing Image of Islam in Japan: The Role of Civil Society in Disseminating Better Information about Islam', Al-Jami'ah, $57.1 \quad$ (2019), 51-82 <https://doi.org/10.14421/ajis.2019.571.51-82>.

${ }^{19}$ Yamaguchi. 
Indonesian Muslim immigrants as the predominant Muslim population in Japan will yield interesting results. Therefore, this research will use qualitative approach to gain deep understanding on how the Indonesian Muslim immigrants adapt to Halal dietary issues in Japan. The study of this new topic uses different approaches shows the novelty of this research.

The purpose of this research is to assess the challenges and adaptation strategies of Indonesian Muslim immigrants in Japan. Previous studies have revealed that one's religiousness influence their consumption behavior. Therefore, the different levels of religiosity would shape different strategies of adaptation. This study examines how Indonesian Muslim immigrants cope with their Halal dietary restrictions in regard to the unusual food choices in Japan. Also, it looks deeper into how their relationships shaped their new lifestyle in Japan, specifically daily food consumption. The result of this study will give a clearer picture of the challenges faced by Muslim immigrants and the type of adaptations they initiate.

This research uses qualitative approach with the main informants hailing from Indonesian Muslim immigrants in Japan. The informants were selected using purposive sampling in accordance with predetermined criteria, namely Indonesian immigrants who are Muslim and live or had lived in Japan. For subjects who no longer live in Japan, the category sought is those who had left Japan only the last two years with an indication that the memories of their life experiences there being considerably good. Meanwhile, for informants who still live in Japan, the criterion is that they have lived in Japan for at least one year and that they have made the necessary adaptations after entering Japan. The informants are scattered in various locations in Japan: urban areas (Tokyo, Yokohama, Fukuoka, Kanagawa), suburban areas
(Beppu, Oita), rural areas (Hokota, Gunma). The interviews were conducted online using Whatsapp, Zoom and Instagram due to the difficulties of arranging in-person meetings during the Covid-19 pandemic. The observations through media and documentations from reports and journals are used as secondary data.

\section{Muslim Immigrants' Narrative}

The Muslim population in Japan may be small, but with the country's aging population and lack of human resources more and more Muslim immigrants are coming to Japan in search of opportunities. Eighty to $90 \%$ of Muslim population in Japan immigrated during the mid1980s and early 1990s, mainly for economic reasons ${ }^{20}$. Japan's economic boom in 1980 has opened thousands influx of Muslims migrant workers from Muslim countries in Asia. The search for employment became the main reason for immigrants from Pakistan, Bangladesh, Iran, Indonesia and Malaysia to enter Japan. Some of these immigrants married Japanese citizens and obtained legal residences ${ }^{21}$ and their descendants form the majority of Muslims in Japan's society today. $^{22}$

The steady growth of Muslims as a minority has created a strong bond inside their community. Even as a minority, the Muslim population spread throughout Japan. In each prefecture the Muslim population always form a community to support each other. The Country Report Series of Japan in 2019 explained that the majority of Muslim Population in Japan are from Asian origins with Indonesian community as the largest, followed by other major Muslim countries like Pakistan, Bangladesh, Malaysia and so forth ${ }^{23}$. The list still goes on but there is no official statistics of the ethnic contribution of the Muslim community in Japan.
${ }^{20}$ Emile A Nakhleh, Keiko Sakurai, and Michael Penn, 'Islam in Japan: A Cause for Concern?', Asia Policy, 5.5 (2008), 61-104.

21 Fauziah Fathil and Fathiah Fathil, 'Islam in Minority Muslim Countries: A Case Study on Japan and
Korea', World Journal of Islamic History and Civilization, 1.2 (2011), 130-41 < http://irep.iium.edu.my/24131/>.

22 SESRIC.

${ }^{23}$ SESRIC. 
The native Japanese Muslims also count for big portion of the Muslim community. The number of Japanese converts continue to grow and could be divided into two types: men who are familiar with Islamic culture and women who are married to Muslim foreigners. ${ }^{24}$ According to Tanada's calculation, until the end of June 2018, the number of Japanese Muslims are approximately 43,000 people, of whom 13,000 were presumed to be those who converted upon marriage, 25,000 were either children born to Japanese Muslim parents or interracial parents, 3,000 were naturalized Japanese citizens and their Japanese partners, and the other 2,000 were those who converted ${ }^{25}$.

This number is predicted to keep increasing in the future with the new law that expects more foreign workers in the future. The Japanese government has amended Immigration Control and Refugee Recognition Act in 2018 to address the aging population and negative population growth which has led to rising labor shortages in Japan. This new law allows foreigners with specified skills to work in certain sectors for five years. The plan is to allow up to 340,000 foreign workers to be admitted to meet the labor shortage and human resources shortfall of 1.45 million within 5 years. ${ }^{26}$ This new policy also provides more opportunities for immigrant Muslims to enter Japan as a worker. However, due to the spread of Covid-19 pandemic in the end of 2019 the law is not fully effective yet since Japan's immigration has locked down the country to prevent the spreading of viruses.

Moreover, Japan also has opened opportunities for International students to continue their studies in Japan with better career prospects if they do job hunting in Japan. Some scholarships from the local government specifically target awardees who has the intention to work in the local industry after graduation. For example, the Aichi Scholarship Program from Aichi Prefectural Government Japan Student Services Organization required their students to be highly expected to seek employment within the Aichi Prefecture.

Based on the annual survey of International Students Survey in Japan in year of 2020, the number of International students in Japan has been increasing each year until the pandemic Covid-19 led to a decline of $10.4 \%$ from last year, 312.124 students in 2019 to 279.597 students in 2020. The same data also documented the student population from Muslim countries toward the overall number of international students in Japan: Indonesia (2.2\%), Bangladesh (1,1\%), Malaysia $(1,0 \%)$, Uzbekistan $(0,5 \%)$, Pakistan $(0,2 \%)^{27}$.

Muslims from Indonesia has significantly contributed to the Muslim population in Japan, not only from number of international students, but also the number of immigrant workers. Data from the National Agency of Placement and Protection of Indonesian Migrant Workers Report in 2018 show that the placement of nurses and care workers in Japan has continued to increase over the last three years ${ }^{28}$. Additionally, the Indonesian government also regards Japan's new law of admitting specified skill workers as a good opportunity for Indonesian migrant workers. Looking at this trend we cannot deny that the Muslim population from Indonesia will keep growing in the future.
${ }^{24}$ Nakhleh, Sakurai, and Penn.

25 Hirofumi Tanada, "Estimate of Muslim Population in the World and Japan, 2018” 料世界と日本 のムス リム人口 2018 年 店田 廣文', Ningenkagaku Kenkyū, 32.2 (2019), 253-62.

${ }^{26}$ Yoshinori Oki, Mitsui \& Co. Global Strategic Studies Institute Montbly Report May 2019, 2019 <https://www.mitsui.com/mgssi/en/report/detail/_icsF iles/afieldfile/2019/07/03/1905d_oki_e.pdf>.
27 jasso, 'Result of an Annual Survey of International Students in Japan 2020', March, 2021, 1-4 <https://www.studyinjapan.go.jp/en/_mt/2021/04/date2 020z_e.pdf $>$.

28 BP2MI, Data Penempatan dan Pelindungan Pekerja Migran Indonesia (PMI) Tahun 2019, 2019 <https://bp2mi.go.id/uploads/statistik/images/data_19$02-$

2020_Laporan_Pengolahan_Data_BNP2TKI__2019(2). pdf $>$. 
Indonesian Muslim Immigrant in Japan Facing Halal Food Challenges

Social Life Issues

Research from Okayama University has highlighted the social life difficulties of Muslim students in Japan. The results found four major points, "difficulty due to restrictions on eating and drinking," "difficulty regarding worship habits," "difficulty due to the influence of the mass media," and "difficulty due to behavioral restrictions," and eight sub-items associated with them ${ }^{29}$. From this, we could understand that the struggle to maintain Halal dietary in Japan is one of the main issues for Muslim immigrants.

As the proverb says: "When in Rome, do as Romans do": some Muslim immigrants do not follow the Halal rules and this facilitates their bond and adaption to their surroundings. The interviews' results also showed that it is hard to follow 100\% religious rules while living in Japan, especially regarding Halal food consumption. Based on the informant $\mathrm{B}^{30}$ who is a Graduate student who has been living in Japan for 4,5 years since his undergraduate study, he explained that He wants to live freely and socialize with Japanese people while living in Japan. This made him choose to only be strict on not consuming pork, while consuming other non-Halal meat. When hanging out with Japanese friends for Nomikai ${ }^{31}$, in order to socialize with his Japanese friends he doesn't mind eating non-Halal food and drinking beer which contradicts with his religion. This attitude is also found with informants A, C, D, and E.

Informant $\mathrm{A}^{32}$ stated that in the Japanese perspective, the drinking culture in nomikai (drinking meets) is an important event for
Japanese workers. The social setting in this culture helps them to build closer relationship between colleagues, juniors and their superiors and clients. "There is social pressure to join nomikai ... if I don't drink, I might feel left out and difficult to feel the togetherness with my coworkers if I don't experience the same drunk effect from the alcohol."

Most of the immigrant workers that have been interviewed explained that they have close relationship to the Japanese community because they interact with them every day. They rarely meet other Indonesian or even other Muslims. Informant $C^{33}$ said that the community around her has important effects on her dietary habits. Since she does not have close relationship with the Muslim community around her, she does not have any support system to maintain the religious habit to consume Halal food.

On the other hand, there are also people who try to do their obligation as a Muslim properly by following strict rules of Halal dietary. The following is an interesting statement by informant $\mathrm{F}^{34}$ who has been living and working in Japan for 5 years:

"It is not about how we adapt and change our self in order to socialize with other people, it is about how we put our self in the environment that accepts and respects us for who we are."

She said that while working with Japanese people she always explained to them what she cannot eat and drink as a Muslim. Fortunately, her colleagues respect her beliefs even sometimes only chooses restaurants that provide food she can consume.

pubs or basically drinking houses that mostly open at night and served various Japanese dishes and alcoholic beverage like sake and beer.

${ }^{32}$ Informant A, (Working in Japanese Company) is living in Metropolitan Area) interview, (19 March 2021)

${ }^{33}$ Informant C, (Working in Japanese Company) is living in Metropolitan Area) interview, (25 March 2021)

${ }^{34}$ Informant F, (Working in Japanese Company) was living in Metropolitan Area) interview, (23 March 2021) 
The Informant $\mathrm{F}^{35}$, informant $\mathrm{G}^{36}$ and informant $\mathrm{H}^{37}$ are categorized as devoted Muslims. They practiced the daily five prayers and followed strict Halal dietary rules. They won't consume meat without the Halal label and always make sure to check the ingredients of every food they purchase. They also actively join the Muslim community events like Muslim gatherings, seminars, prayers in mosque, etc. The close relationship with Muslim community helped them to maintain their religiosity and identity as a Muslim.

The informant $G$ and Informant $H$ are housewives of Japanese husbands. They have a closer relationship towards the Muslim community compared to non-Muslim communities. Based on the interview with Informant $G$, the Muslim community in her city often hold gatherings for Muslims and sharing sessions about Halal food especially for new international students.

"In Beppu City Mosque every year we will organize Halal Guidance for new Muslim students. We also have Indonesia Muslim gathering called Taslima where we recite Qur'an, sharing knowledge of Islam and eating Indonesian food"

The interview above showed that a closer relationship with the Japanese community makes Indonesian Muslim immigrants more flexible in their food consumptions and alcohol. The social setting in their work environment exerts pressure to be more adaptable to Japanese culture. However, someone who have strong religious identity will stick to Islamic law. They will explain their religion's restrictions beforehand and expect that the Japanese people understand it. On the contrary, a closer relationship to the Muslim community usually helps Muslim immigrants to follow Halal dietary rules. The community allows the immigrants to have more networks and information to get Halal food. The community gathering events also help them to sustain their religiosity by sharing religious knowledge and give them sense of belonging.

\section{Accessibility and V ariety of Halal Food Products}

The accessibility of Halal food products is getting easier due to increased interest towards the Halal market. More Halal-labeled food items is being sold in supermarkets throughout Japan. One of them is Gyomu Super. This supermarket had around 800 branches in April 2018, which is famous for its large selection of food products, large packaging and low prices. Informant $\mathrm{C}^{38}$ explained:

"Gyomu Super is a big supermarket that also provides Halal food and imports products that have Halal labels, some of them are from Indonesia. Usually, if I want to get Halal chicken I will buy it there"

However, since she is a full-time employee in a Japanese company who has a busy schedule, she prefers to buy food that is more convenient and practical for her daily life. She favors Japanese meat rather than Halal meat because she can have more choices that suits her lifestyle. The majority of Halal meat products in Japan are sold in large packaging. For example, imported Halal chickens are usually packaged in $2 \mathrm{~kg}$ packs. Therefore, the lack of variety has made Halal products less attractive compared to non-Halal products.

Technical interns who work in agriculture, livestock, and factories that are mostly located in rural areas often find it difficult to buy Halal food. In the remote areas only small shops or convenience stores are available. Moreover, there is very limited or even no public transportation due to the sparse population of rural areas in Japan. Informant $\mathrm{E}^{39}$ is a technical intern who
${ }^{35}$ Informant F, (Working in Japanese Company) was living in Metropolitan Area) interview, (23 March 2021)

35 Informant G, (Housewife of Japanese Husband) living in Sub Urban Area) interview, (23 March 2021)
${ }^{37}$ Informant H, (Housewife of Japanese Husband) living in Rural Area) interview, (31 March 2021)

38 Informant C, (Woring in Japanese Company) living in Metropolitan Area) interview, (25 March 2021)

${ }^{39}$ Informant E, (Technical Intern) living in Rural Area) interview, (04 April 2021) 
works in an agriculture farm in a small city called Tonosho. He described that where he lives is far from major economic centers and it is difficult to get a holiday because of his busy work at the farm.

Accessibility to Halal food does not really depend on how far the location is to Halal store. The informant $\mathrm{H}^{40}$ is a housewife with two children who just moved to a small city in Gunma Prefecture, Japan. She said:

"In Gunma we have several Halal shops that also sell fresh Halal meat. Additionally, a lot of South Asian families reside here who help me to access information about Halal food and raise my children in the Islamic environment."

Her husband is a Japanese-Pakistani imam ${ }^{41}$ who is often invited for audit and inspection to Japanese companies that want to obtain Halal certificates. Therefore, her family has very strict Halal standards. Her family rarely eats outside and prefers to cook everything by themselves. In the supermarket she will only buy raw ingredients that have not been mixed or processed several times, such as: salt, fresh vegetables, pepper, etc. However, despite her strict rules she said that it is easy to find Halal products especially since more Halal food could be bought online. Additionally, based on "The State of Global Islamic Economy Report 2020/2021", the spread of pandemic Covid-19 has accelerated and transformed the Halal food sector through digitalization. Ecommerce and online grocery/delivery became critical as people had to stay at home due to social distancing restrictions. ${ }^{42}$

The accessibility to Halal food does not depend on the location anymore, but the routine and social community. The busy schedule of Japanese workers made it difficult for them to access Halal food or mingle with the Muslim community. They prefer something faster and convenient for their daily consumption. On the contrary, the housewife's main job is to take care of the family's health which has made them more concerned about what to eat. They also have more time to join gatherings and share information with the Muslim community where they could find Halal food, such as where to get it, which product is Halal and not, how to cook, etc. This information sharing has make it easier for housewives to get Halal food products compared to people who are not close to the Muslim community.

\section{Halal Food Label Issues}

The confirmation of the Halal-ness of a product has become additional consideration for Muslim customers. The assurance of the Halalness of products is usually provided in the form of a label in the package. This label can be acquired after qualifying the Halal certification audit and assessment from an Islamic certification organization. ${ }^{43}$ The existence of this organization is very important to make sure that the published certificates are in accordance with Sharia Law. However, Japan does not have a single Halal certification body that has the main power to publish Halal certification such as MUI in Indonesia or JAKIM in Malaysia. Previous research by Yamaguchi also explored the same issues. There is no uniform standard for the acquisition and renewal of Halal certification. ${ }^{44}$ Japanese companies that want to export their products to Muslim countries especially in Southeast Asia and East Asia usually cooperate with several associations such as the Japan Muslim Association (JMA), Japan Islamic Trust (JIT), and Japan Halal Association (JHA). These three bodies have been recognized by JAKIM (Malaysia), MUI
${ }^{40}$ Informant H, (Housewife of Japanese Husband) living in Rural Area) interview, (31 March 2021)

41 A male person who considerate as a leader in Muslim community.

42 Dinar Standard.
${ }^{43}$ M. Pradana, R. Huertas-García, and F. Marimon, 'Purchase Intention of Halal Food Products in Spain: The Moderating Effect of Religious Involvement', International Food Research Journal, 27.4 (2020), 735-44.

44 Yamaguchi. 
(Indonesia), ESMA (UAE), MUIS (Singapore), and GCC Accreditation Center (Saudi Arabia). ${ }^{45}$

On the other hand, the small and local business usually prefer to consult to the closest Muslim Association they could find. Based on Informant H's explanation, there are even cases where the certification published are only from an agreement of a group of Muslim people or Mosque representative. This could be a big issue because not all Muslim people have the knowledge and deep understanding of Halal $f i q h^{46}$. Even, the imams or Muslim scholars that are considered qualified to decide Halal or Haram usually do not even know that a loaf of bread or chocolate in Japan could be Haram for them. This is due to the differences of food manufacturing and culture of Japan and Indonesia. Therefore, Halal food education is not only important for business people but also for foreigners.

For Muslims immigrants living in a nonIslamic country like Japan, finding food products with Halal labels is like discovering a treasure. Most food products in Japan do not have any Halal labels, so Muslims need to read the ingredients carefully before they purchase certain products. Everyone has their own benchmark of ingredients before they decide to buy it. Informant $A$, informant $C$ and informant $E$ said that they do not read the ingredients because it is very inconvenient for their daily life. Whereas, informant $\mathrm{B}$ and informant $\mathrm{C}$ sometimes check if the ingredient list contain the kanji “' 豚' , or”ポークエキス” which means the food contains pork. On the other hand, the strict group always makes sure to check all possibilities of animal or alcohol contamination. Informant $\mathrm{H}$ even explained that she will ask three mandatory questions before purchasing a certain Japanese food product: 1 . Is it derived from plants or

45 Shannaz Mutiara Deniar and Tonny Dian Effendi, 'Halal Food Diplomacy in Japan and South Korea', Journal of Social and Political Sciences, 2.3 (2019), 805-13 <https://doi.org/10.31014/aior.1991.02.03.121>.

46 The term for Islamic jurisprudence refers to a process by means of which jurists derive sets of guidelines, rules and regulations from the rulings laid down in the animals? 2. Does it contain alcohol? If yes, what type of alcohol and how many percent is the alcohol content? 3. Is there any possibility of animal contamination in the manufacturing process?

With the growing interest of the Halal market in Japanese food industry, more restaurants are offering Halal menus for the Muslim customers. Based on data from www.halalgourmet.jp by October 2017, there are 788 restaurants in Japan that provide Halal food options, while 161 of them have obtained Halal food certification. ${ }^{47}$ The limited number of restaurants with Halal certification also made Muslim immigrants difficult to eat out. The people who do not eat pork will choose menus that they can consume. The stricter person who only eats Halal meat will prefer Halal-friendly restaurants, vegetarian restaurants, South Asian restaurants, or fish-based restaurants even though it does not have Halal certification. However, people who are so meticulous toward Halal standards only come to restaurants with Halal certification that do not serve any menus that are considerably Haram. This is because Halal-friendly restaurants usually cannot give $100 \%$ guarantee that the cooking and cleaning process of the Halal dishes are being separated fully from the other dishes.

\section{Halal Dietary Adaptation Typology Using Robert K. Merton Theory}

The different culture and norms in Japan have pushed Muslim immigrants to adapt to the environment. Although they share a common religion, Muslims in Japan have shown diverse types of adaptation towards their daily food consumption. As the previous studies have found, the level of obedience and religiosity of a person determines their respective preferences in

Qur'an and the teachings and living example of the Prophet Muhammad (pbuh), the Sunnah. The knowledge of Islamic law that specifically discusses legal issues that regulate various aspects of human life.

47 Lufi Wahidati and Eska Nia Sarinastiti, 'Perkembangan Wisata Halal di Jepang', Jurnal Gama Societa, 1.1 (2018), 9-19. 
consuming Halal food. Therefore, for people that exhibit a lack of religiosity tend to be more flexible toward Sharia law.

To understand this case, this research will use Strain Theory from Robert Merton that have categorized adaptation into five modes: Conformity, Innovation, Ritualism, Retreatism, and Rebellion. ${ }^{48}$ Merton explained that in order to keep the social structure in balance, an individual should adapt themself to meet social goals. In this case, the social goal is to be "a good Muslim that follow the Sharia law". The acceptable method in reaching out for the goals are called the institutionalized or legitimate means, in this case by "only consuming Halal food as instructed in Islamic law". "However, since there is no equal access to goals, the deviant group will choose different types of methods to achieve the goals. This research has found that some of adaptation strategy taken by Muslim Immigrants Indonesia in Japan could be categorized into Merton's Typology of Adaptation: (a). Conformity: acceptance of both cultural goals and institutionalized means. In order to become a good Muslim, they follow the Sharia rules completely by making sure that what they eat is $100 \%$ Halal and in accordance with religious law. The easiest way to distinguish this group is by looking at how they consume meat. The strictest group only consume meat with Halal labels and not consume food or drink that contain alcohol. They always check the ingredients for any possible contaminations of animal substances and alcohol, even going as far as calling the food company to make sure the manufacturing process. They will also only visit restaurants with Halal certification that specifically serve Halal menus. Nevertheless, there are also less strict groups that would still consume the food products even though they cannot $100 \%$ guarantee the Halal-ness. Usually they do not have any issue eating in non-Halal labeled restaurants if they can find fish or vegetarian menus. This group usually prefer to cook at home rather than eating out because they can make sure all the ingredients they use are Halal.

(b). Innovation: an individual who has assimilated the cultural emphasis upon the goal without internalizing the institutional norms, but choose different ways and means for its attainment. This group of people realize their identity as a Muslim but choose more lenient rules that suit their condition to adapt to life in Japan. They still prefer to consume meat with Halal label, but they also do not mind eating non-Halal labelled meat as long as it is not pork. Also, if it does not have the Kanji pork in the label, it is still consumable for them. Eating out is not an issue because they can choose food that does not use pork. They also drink alcohol occasionally in order to socialize with the Japanese community.

(c). Ritualism: people who are abandoning the cultural goals but follow institutionalized means to keep their aspirations satisfied. In this case, this group of people usually choose to not consume pork not because of the religious reason but rather due to cultural background. In Indonesia, especially in Muslim environments it hard to find food that contain pork. These people are not used to eating pork and still prefer chicken and beef as better choices. Additionally, due to their flexible character, it is easier for them to socialize with the Japanese community. It is fine for them to consume alcohol or food that contains pork as long as it is not in the form of meat. When purchasing food, they will look more into the price, taste, and variation rather than the Halal label.

(d). Retreatism: rejection of both the goals of the culture, and the institutionalized means to achieve them. This type of individual usually does not care anymore with Halal and Haram or even their status as a Muslim. They have immersed with Japanese culture and community. They also
48 Daniel S. Murphy and Mathew B. Robinson, 'The Maximizer: Clarifying Merton's Theories of Anomie and
Strain', Theoretical Criminology, 12.4 (2008), 501-21 <https://doi.org/10.1177/1362480608097154>.

${ }^{49}$ Murphy and Robinson. 
do not have any close relationship with other Muslims around them. Thus, they do not have any concern about violating Islamic law on the obligation to consume Halal food and drinks.

(e). Rebellion: rejection of both the goals of the culture and the institutionalized means. However, this group usually has developed their own substitute for cultural goals and institutionalized means. They also try to replace both elements of the society with new different goals and means. In this research, the rebellion type of adaptation was not found in the Indonesian Muslim Immigrants.

\section{Conclusion}

The growing population of Muslim Immigrants in Japan has contributed to the development of the Halal food industry. There are more Halal-friendly restaurants and Halal food products that are available to the society. However, there are still challenges faced by Muslims in Japan to obtain Halal food products. In order to easily blend and interact with Japanese environment around them, Muslim immigrants will usually change their food choices when they hangout. Therefore, the closer they are with the Japanese community, the harder it is to follow Halal dietary consumption. On the contrary, good relationship with the Muslim community helps them to obtain information about Halal food products and maintain Halal dietary consumption. The availability and variety of Halal food products are so limited that it makes it less appealing for people with busy schedules. Additionally, there is no one legal Halal certification body that has the main power to publish Halal certification in Japan. The guarantee of Halal-ness of Halal labels in Japan is considerably weaker than other countries like Indonesia, Singapore, Malaysia, etc. Therefore, in order to face these challenges, the Muslim immigrants have showed different types of adaptation that are suitable for their condition in Japan.

Using Robert K. Merton Theory, there are four types of adaptation strategy of Halal dietary consumption by Indonesia Muslim Immigrants in
Japan: Conformity, Innovation, Ritualism, and Retreatism. The rebellion type has not been found in this research. The Conformity type is shown by a group of Muslims that strictly follow the Sharia law of Halal foods and drinks. The Innovation type is people who affirm their identity as Muslim by only following the Sharia law that is convenient to them, that is why they have more flexibility in regard to alcohol and non-halal food. The Ritualism type are immigrants who are not fully adapted to the Japanese foods and drinking habits because they are not used to do it in Indonesia. The retreatism type is group of people who do not acknowledge their Muslim identity and are already used to the Japanese eating and drinking habits.

\section{References \\ Journals}

Ainur Rofiq \& Titan Achsan, 'Examining the Impacts of Religiosity, Attitude, and Subjective Norm Toward Intention to Purchase Halal Food: A Study on Indonesian Muslim Consumers', Jurnal Ilmiah Mahasiswa Fakultas Ekonomi Dan Bisnis, 05 (2017)

$<$ https://jimfeb.ub.ac.id/index.php/jimfeb /article/view/3850>

Amin, Ali, 'From Mushalla to Mosque: The Formation of South and Southeast Asian Muslim Communities in Japan', Al-Albab, 8.1 (2019), $<$ https://doi.org/10.24260/alalbab.v8i1.10 $50>$

Annabi, Carrie Amani, and Olufunbi Olajumoke Ibidapo-Obe, 'Halal Certification Organizations in The United Kingdom: An Exploration of Halal Cosmetic Certification', Journal of Islamic Marketing, 8.1 (2017), 107-26 $<$ https://doi.org/10.1108/JIMA-06-2015$0045>$

Arata, Mariko, 'Getting Halal Food in the Netherlands: From Indonesian Consumers' Perspective', in Proceedings of the International Workshop on Halal Food Consumption in East and West, 2018, pp. 35-48 https://www.academia.edu/ 
Deniar, Shannaz Mutiara, and Tonny Dian Effendi, 'Halal Food Diplomacy in Japan and South Korea', Journal of Social and Political Sciences, $2.3 \quad$ (2019), 805-13 <https://doi.org/10.31014/aior.1991.02.03. $121>$

Fasa, Muhammad Iqbal, 'Critical Review: Is Religiousity an Important Determinant on Muslim Consumer Behavior in Malaysia?', IJRDO-Journal of Applied Management Science, 2.8 (2016), 13-21

Fathil, Fauziah, and Fathiah Fathil, 'Islam in Minority Muslim Countries: A Case Study on Japan and Korea', World Journal of Islamic History and Civilization, 1.2 (2011), 130-41 $<$ http://irep.iium.edu.my/24131/>

Mokhlis, Safiek, 'Relevancy and Measurement of Religiosity in Consumer Behavior Research', International Business Research, 2.3 (2009) $<$ https://doi.org/10.5539/ibr.v2n3p75>

Murphy, Daniel S., and Mathew B. Robinson, 'The Maximizer: Clarifying Merton's Theories of Anomie and Strain', Theoretical Criminology, $12.4 \quad$ (2008), 501-21 <https://doi.org/10.1177/13624806080971 $54>$

Nakano, Sachiko, Yuri Okunishi, and Tomoko Tanaka, ‘在日ムスリム留学生の社会生 活上の困難 "Social Life Difficulties of Muslim Students in Japan"', 岡山大学大学 院社会文化科学研究科紀要, 39, 2015, 137-51

<http://ci.nii.ac.jp/naid/120005593532/ja/ $>$ Ainur Rofiq \& Titan Achsan, 'Examining the Impacts of Religiosity, Attitude, and Subjective Norm Toward Intention to Purchase Halal Food: A Study on Indonesian Muslim Consumers', Jurnal Ilmiah Mahasiswa Fakultas Ekonomi Dan Bisnis, 05 (2017)

$<$ https://jimfeb.ub.ac.id/index.php/jimfeb /article/view/3850>

Amin, Ali, 'From Mushalla to Mosque: The Formation of South and Southeast Asian Muslim Communities in Japan', Al-Albab, 8.1 (2019), $<$ https://doi.org/10.24260/alalbab.v8i1.10 $50>$
Annabi, Carrie Amani, and Olufunbi Olajumoke Ibidapo-Obe, 'Halal Certification Organizations in The United Kingdom: An Exploration of Halal Cosmetic Certification', Journal of Islamic Marketing, 8.1 (2017), 107-26 $<$ https://doi.org/10.1108/JIMA-06-20150045>

Arata, Mariko, 'Getting Halal Food in the Netherlands: From Indonesian Consumers' Perspective', in Proceedings of the International Workshop on Halal Food Consumption in East and West, 2018, pp. 35-48 $<$ https://www.academia.edu/>

BP2MI, Data Penempatan Dan Pelindungan Pekerja Migran Indonesia (PMI) Tabun 2019, 2019 <https://bp2mi.go.id/uploads/statistik/im ages/data_19-02-

2020_Laporan_Pengolahan_Data_BNP2T KI___2019(2).pdf>

Deniar, Shannaz Mutiara, and Tonny Dian Effendi, 'Halal Food Diplomacy in Japan and South Korea', Journal of Social and Political Sciences, $2.3 \quad$ (2019), 805-13 <https://doi.org/10.31014/aior.1991.02.03. $121>$

DinarStandard, 'State of the Global Islamic Economy Report 2020/2021', Salaam Gateway, 2019, 3-4 $<$ https://cdn.salaamgateway.com/specialcoverage/sgie19-20/full-report.pdf>

Fasa, Muhammad Iqbal, 'Critical Review: Is Religiousity An Important Determinant On Muslim Consumer Behavior In Malaysia?', IJRDO-Journal of Applied Management Science, 2.8 (2016), 13-21

Fathil, Fauziah, and Fathiah Fathil, 'Islam in Minority Muslim Countries: A Case Study on Japan and Korea', World Journal of Islamic History and Civilization, 1.2 (2011), 130-41 <http://irep.iium.edu.my/24131/>

Hajis, Hiji, 'The Number of Muslims in Japan Is Growing Fast', The Economist, 2021 <https://www.economist.com/asia/2021/ 01/07/the-number-of-muslims-in-japan-isgrowing-fast>

Halawa, Abdelhadi, 'Acculturation of Halal Food to the American Food Culture through Immigration and Globalization: A Literature 
Review', Journal of Ethnic and Cultural Studies, $5.2 \quad$ (2018), 53-63 <https://doi.org/10.29333/ejecs/89>

Jasso, 'Result of an Annual Survey of International Students in Japan 2020', March, 2021, 1-4 <https://www.studyinjapan.go.jp/en/_mt/ 2021/04/date2020z_e.pdf>

Mokhlis, Safiek, 'Relevancy and Measurement of Religiosity in Consumer Behavior Research', International Business Research, 2.3 (2009) $<$ https://doi.org/10.5539/ibr.v2n3p75>

Murphy, Daniel S., and Mathew B. Robinson, 'The Maximizer: Clarifying Merton's Theories of Anomie and Strain', Theoretical Criminology, $12.4 \quad$ (2008), 501-21 $<$ https://doi.org/10.1177/13624806080971 $54>$

Nakano, Sachiko, Yuri Okunishi, and Tomoko Tanaka, ‘在日ムスリム留学生の社会生 活上の困難 "Social Life Difficulties of Muslim Students in Japan", 岡山大学大学 院社会文化科学研究科紀要, 39, 2015, 137-51

<http://ci.nii.ac.jp/naid/120005593532/ja/ $>$

Nakhleh, Emile A, Keiko Sakurai, and Michael Penn, 'Islam in Japan: A Cause for Concern?', Asia Policy, 5.5 (2008), 61-104

Oki, Yoshinori, Mitsui \& Co. Global Strategic Studies Institute Monthly Report May 2019, 2019 $<$ https://www.mitsui.com/mgssi/en/repor t/detail/__icsFiles/afieldfile/2019/07/03/1 905d_oki_e.pdf>

Pradana, M., R. Huertas-García, and F. Marimon, 'Purchase Intention of Halal Food Products in Spain: The Moderating Effect of Religious Involvement', International Food Research Journal, 27.4 (2020), 735-44

Ramly, Zulkufly, Lau Teck Chai, and Choe Kum Lung, 'Religiosity as a Predictor of Consumer Ethical Behaviour: Some Evidence from Young Consumers from Malaysia', Journal of Business Systems, Governance and Ethics, 3.4 (2008)

<https://doi.org/10.15209/jbsge.v3i4.147>

Rehman, Ateeq-ur-, and Muhammad Shahbaz Shabbir, 'The Relationship Between
Religiosity and New Product Adoption', Journal of Islamic Marketing, 1.1 (2010), 63-69 <https://doi.org/10.1108/17590831011026 231>

SESRIC, 'Muslim Communities and Minorities in Non-OIC Member States: Japan', Global Muslim Diaspora Project. Human and Social Development Studies., 2019, 8

Tanada, Hirofumi, "Estimate of Muslim Population in the World and Japan, 2018” 料 世界と日本のムスリム人口 2018 年店 田 廣文', Ningenkagaku Kenkyuu, 32.2 (2019), 253-62

Wahidati, Lufi, and Eska Nia Sarinastiti, 'Perkembangan Wisata Halal Di Jepang', Jurnal Gama Societa, 1.1 (2018), 9-19

Yakin, Ayang utriya, and Ima Sri Rahmani, 'Halal Food Consumption among the Indonesian Muslim Minority in Belgium', in Proceedings of the International Workshop on Halal Food Consumption in East and West' (Tokyo: Institute for Asian Muslim Studies, Waseda University, 2018), pp. 123-50

Yamaguchi, Hiroko Kurosaki, 'The Potential and Challenge of Halal Foods in Japan', Journal of Asian Rural Studies, 3.1 (2019), 1 <https://doi.org/10.20956/jars.v3i1.1712>

Yulita, Irma Rachmi, and Susy Ong, 'The Changing Image of Islam in Japan: The Role of Civil Society in Disseminating Better Information about Islam', Al-Jami'ah, 57.1 (2019), $51-82$ $<$ https://doi.org/10.14421/ajis.2019.571.51 $-82>$

\section{Online Database}

BP2MI, Data Penempatan Dan Pelindungan Pekerja Migran Indonesia (PMI) Tabun 2019, 2019 $<$ https://bp2mi.go.id/uploads/statistik/im ages/data_19-02-

2020_Laporan_Pengolahan_Data_BNP2T KI__ 2019(2).pdf>

DinarStandard, 'State of the Global Islamic Economy Report 2020/2021', Salaam Gateway, 2019, 1-178 $<$ https://cdn.salaamgateway.com/specialcoverage/sgie19-20/full-report.pdf $>$ 
Hajis, Hiji, 'The Number of Muslims in Japan Is Growing Fast', The Economist, 2021 $<$ https://www.economist.com/asia/2021/ 01/07/the-number-of-muslims-in-japan-isgrowing-fast $>$

Jasso, 'Result of an Annual Survey of International Students in Japan 2020', March, 2021 https://www.studyinjapan.go.jp/en/ mt/2 021/04/date2020z e.pdf
Nakhleh, Emile A, Keiko Sakurai, and Michael Penn, 'Islam in Japan: A Cause for Concern?', Asia Policy, 5.5 (2008), 61-104

Oki, Yoshinori, Mitsui \& Co. Global Strategic Studies Institute Mnthly Report May 2019, 2019 <https://www.mitsui.com/mgssi/en/repor t/detail/_icsFiles/afieldfile/2019/07/03/1 905d_oki_e.pdf $>$ 